\title{
Doğal Lif Takviyeli Kompozitlerin Burkulma Davranışına Deniz Suyunun Etkisi
}

\author{
Ayșe ÖNDÜRÜCÜ1 ${ }^{1}$ Mustafa MUZOĞLU² \\ 1,2Süleyman Demirel Üniversitesi, Mühendislik Fakültesi, Makine Mühendisliği Bölümü, 32260, Isparta \\ ${ }_{1}^{1}$ (ORCID: https://orcid.org/0000-0002-0319-4256) \\ ${ }^{2}$ (ORCID: https://orcid.org/0000-0003-1761-1556)
}

(Alınıș / Received: 13.06.2018, Kabul / Accepted: 03.04.2019, Online Yayınlanma / Published Online: 16.04.2019)

\begin{abstract}
Anahtar Kelimeler
Kompozit malzeme, Doğal lif,

Burkulma davranıșı,

Deniz suyu,

İstifleme dizilimi
\end{abstract}

\begin{abstract}
Özet: Bu çalışmada, deniz suyunda bekletilen farklı istifleme dizilimine sahip doğal lif takviyeli cam elyaf kompozit numunelerin kritik burkulma yükleri deneysel olarak incelenmiştir. Deneylerin gerçekleştirilebilmesi için fiber olarak jüt ve cam kumaşlar, matris olarak da epoksi reçine kullanarak farklı konfigürasyonlarda kompozit malzemeler üretilmiștir. Takviye ve matris arası yapışma miktarının artırılması için jüt kumaşlara alkali işlem uygulanmıştır. Kompozit numuneler deniz suyunda ve oda koşullarında 2 ay (60 gün) boyunca bekletildikten sonra burkulma deneyine tabi tutulmuşlardır. Deneyler sonucunda elde edilen veriler doğrultusunda, doğal lif takviyeli kompozit numunelerin kritik burkulma yükleri belirlenmiștir. Yapılan deneysel çalışma sonucunda, deniz suyunun doğal kompozitlerin burkulma dayanımını olumsuz yönde etkilediği görülmüștür. Simetrik ve antisimetrik dizilimli kompozitler karşılaştırıldığında, Akdeniz suyunda bekletilen antisimetrik $\left(0_{2 c} / 90_{2 j}\right)$ as dizilimli numunelerde meydana gelen kritik burkulma yükünün, $\left(0_{2 c} / 90_{2 j}\right)_{s}$ simetrik dizilime sahip numunelere göre daha düşük olduğu gözlenmiştir.
\end{abstract}

\section{The Effect of Seawater on Buckling Behavior of Natural Fiber Reinforced Composites}

\section{Keywords}

Composite material, Natural fiber,

Buckling behavior,

Sea water,

Stacking sequences

\begin{abstract}
In this study, the critical buckling loads of natural fiber reinforced glass fiber composite specimens with different stacking sequences kept in seawater were experimentally investigated. Jute and glass fabrics as fiber and epoxy resin as matrix were used to produce the composites in different configurations. Alkali treatment was applied to jute fabrics in order to increase the amount of adhesion between the reinforcement and the matrix. Composite specimens were subjected to buckling test kept in seawater and room conditions for two months (60 days). Critical buckling loads of natural fiber reinforced composite specimens were determined in the direction of the data obtained as a result of the tests. As a result of the experimental study, it was seen that sea water influenced the buckling strength of natural composites in the negative direction. When the symmetric and antisymmetric composites were compared, it was observed that the critical buckling stress in the specimens with antisymmetric $\left(0_{2 g} / 90_{2 \mathrm{j}}\right)_{\mathrm{us}}$ kept in Mediterraneanseawater was lower than those with symmetric sequence $\left(0_{2 \mathrm{~g}} / 9_{2} 0_{2}\right)_{s}$.
\end{abstract}

\section{Giriş}

Endüstriyel uygulamaların her geçen gün artması daha iyi özelliklere sahip malzeme gereksiniminin doğmasına neden olmuştur. Düşük maliyetli, uzun ömürlü, çevreye zarar vermeyen, dayanıklı ve geri dönüştürülebilir özellikte yeni ürünler elde etmek amacıyla yapılan çalışmaların önemli bir kısmı kompozit malzemeler üzerine olmaktadır. Kompozit malzeme üretimindeki amaç, aynı veya farklı özelliklerdeki malzemelerin en iyi özelliklerini bir araya getirerek üstün özelliklere sahip yeni bir malzeme olușturmaktır. Günümüzde malzeme bilimine verilen önem gittikçe artmaktadır. Mühendislik tasarım ve uygulamalarında doğal liflerin esas alındığı kompozitlerin araștırılması ve geliştirilmesi ile ilgili çalışmalar son zamanlarda hız kazanmıștır [1-2]. 
Kompozit malzemelerin takviyelendirilmesinde, cam fiber veya karbon fiber gibi sentetik fiberlerin yerine jüt, sisal, keten vb. gibi doğal fiberlerin kullanımı her geçen gün artmaktadır. Çevresel kirliliğin artması sonucu biyolojik olarak parçalanabilirlik, geri dönüştürülebilirlik gibi özelliklerinden dolayı doğal lif takviyeli kompozitler tercih edilmektedir [3]. Doğal fiberler çevreye zarar vermemesi, düşük maliyeti, düşük yoğunluğu, yüksek dayanıklılığı, biyobozunabilir ve yenilenebilir kaynaklar olması, doğada bol miktarda bulunabilmesi ve takım aşınmasının azlığı gibi nedenlerden dolayı inşaat endüstrisi, taşımacılık endüstrisi vb. alanlarda oldukça geniş yer kaplamaktadır [4]. Tüm bu iyi özelliklerine rağmen doğal liflerin düşük ara yüzey yapışma özelliklerine sahip olması, doğal lif takviyeli kompozit malzemelerin cam lifi takviyeli kompozit malzemelere göre düşük mekanik özellikler sergilediğini göstermektedir [5]. Bunun önüne geçebilmek içinde yüzey modifikasyon işlemi yapmak gerekmektedir. $\mathrm{Bu}$ amaçla malzeme üretimine geçilmeden önce jüt kumaşlara alkali işlem, oksidasyon işlemi, plazma işlemi veya UV radyasyon işlemleri gibi yöntemlerden biri uygulanarak lif ve matris arasındaki yapışmayı artırıp, liflerin su emme kapasitesinin azaltılması sağlanmalıdır.

Mukavemet ve yapı elemanlarının tasarlanmasında üç temel karakteristik faktör vardır. Bunlar mukavemet, sertlik ve stabilitedir. Sistemdeki gerilmeler akma ve kopmada belirli bir değeri aşmişsa sistem emniyetsiz haldedir. $\mathrm{Bu}$ tip problemlere gerilme problemi denilmektedir. Burkulma olayında ise bir denge problemi söz konusudur. Eğer denge konumu kararlı değil ise sistemde oluşabilecek en ufak bir farklılık çok büyük şekil değişikliklerine sebep olur ve sistemin tekrar ilk konumuna gelmesi imkânsız hale gelir. $\mathrm{Bu}$ tür problemlere denge (stabilite) problemleri denilmektedir. Burkulmada, denge konumunu dengesiz konumuna getiren yüke kritik burkulma yükü adı verilmektedir.

Literatürde doğal lif takviyeli kompozitlerin üretim aşamasındaki yüzey modifikasyonu işlemleri, jütler ve kompozitlerin burkulma davranışlarının incelenmesiyle ilgili farklı çalışmalar mevcuttur: Seki ve Akşit, \%5 oranındaki $\mathrm{NaOH}$ ile işlem yapılan jüt lifi takviyeli epoksi ve polyester kompozit malzemelerin mekanik özelliklerinin arttığını belirtmişlerdir [3]. Mohanty vd., yüksek yoğunluklu jüt kompozitlerin viskoelastik ve mekanik özelliklerini deneysel yollarla araştırmışlardır [4]. Karabulut ve Aktaş, dokuma jüt kumaşların $\% 0, \% 5, \% 10, \% 15$ oranlarinda $\mathrm{NaOH}$ ile yüzey modifikasyonu sonrasında polyester reçine ile tabakalı kompozit malzeme üretip mekanik özelliklerini deneysel olarak incelemişlerdir [5]. Ramesh vd. sisal-jüt-cam fiber takviyeli polyester kompozitlerin çekme, eğme ve darbe dayanımını araştırmışlardır. Ara yüzey özelliklerini, iç çatlakları ve kırılma yüzeylerinin iç yapılarını SEM kullanarak incelemişlerdir. Çalışma sonucunda sisal-jüt fiberin cam fiber takviyeli polyester (GFRP) ile birleştirilmesinin kompozitin özelliklerini geliştirebileceğini ve cam elyaf takviyeli polimer kompozitler için alternatif bir malzeme olarak kullanılabileceğini göstermiştir [6]. Liu ve Dai, jüt liflerinin alkali işlemden sonra pürüzlü bir yüzey oluşturduğunu ve jüt/polipropilen ara yüzeyindeki dayanıklılığın arttığını rapor etmişlerdir [7]. Bulut ve Erdoğan yapmış oldukları çalışmada, doğal lif takviyeli kompozit malzemelerde ara yüzey etkileşimini arttırmak için kullanılan iyileştirme yöntemlerini detaylı olarak incelemişlerdir [8]. Singh vd., farklı türlerdeki nem, ısı ve hava koşulları içinde bulunan jüt kompozitlerin fiziksel ve mekanik özelliklerini araştıran bir çalıșma yapmışlardır [9]. Akil vd., jüt-cam ve kenaf-cam hibrit polyester kompozitlere eğilme testleri uygulamışlardır. Akustik emisyon deneyleri ile mikro analizler yapmışlardır [10). Boccardi vd., jüt esaslı kompozitlerin karakterizasyonunda kızılötesi termografinin etkisini incelemişlerdir [11]. Chaudhari vd., yaptıkları çalışmada, kimyasal işlem görmüş jüt-polyester kompozitlerin termo-mekanik özelliklerini incelemişlerdir [12].

Akbulut ve Sayman, merkezinde dikdörtgen şeklinde delik bulunan tabakalı kompozit plakaların burkulma yüklerini sonlu elemanlar metodu kullanarak araştırmışlardır [13]. Gençoğlu yapmış olduğu çalışmada, simetrik ve antisimetrik tabaka dizilimine sahip kompozit levhaların farklı oryantasyon açları, delik geometrileri ve boyutları için nümerik burkulma analizlerini gerçekleştirmişlerdir [14]. Chakrabarti ve Sheikh, tabakalı kompozit plakaların burkulma davranıșlarını ince plaka teorisini kullanarak incelemişlerdir [15]. Karakuzu vd., cam lifi - epoksi esaslı kompozit plakaların darbe davranışı üzerine deniz suyunun etkisini araştırmışlardır [16]. Zamri vd. tarafindan yapılan çalışmada, oda sıcaklığında 3 haftalık periyot süresince damıtılmış su, deniz suyu ve asitli su koşullarına maruz kalan jüt/cam fiber takviyeli doymamış polyester hibrid kompozitlerin su emiliminin etkileri araştırılmıştır. Hibrit kompozitin su alım yüzde miktarının artmasıyla eğilme ve basma özelliklerinin azaldığ 1 belirlenmiştir [17].

Kompozit malzemelerin kullanım alanları oldukça geniş olduğundan, farklı ortam koşullarına ve farklı sıcaklık değerlerine maruz kalabilmektedirler. $\mathrm{Bu}$ nedenle bu çalışmada, doğal lif takviyeli kompozit malzemelerin burkulma davranışı üzerine deniz suyunun etkisi araştırılmıştır. Deneysel çalışma için iki farklı fiber (E-cam ve jüt) ve matris olarak da epoksi reçinesi kullanılarak doğal lif takviyeli simetrik ve antisimetrik kompozit malzemeler imal edilmiştir. Kompozit numuneler 60 gün boyunca oda koşullarında kuru ortam ve deniz suyu olmak üzere iki farklı ortamda bekletilmişlerdir. Bekleme süreleri tamamlanır tamamlanmaz numuneler bulundukları ortamdan alınarak hiç bekletilmeden burkulma deneyine tabii tutularak, deniz suyunun ve farklı 
istifleme diziliminin doğal kompozitlerin burkulma davranışı üzerine etkileri araștırılmıștır.

\section{Materyal ve Metot}

Kompozit malzeme üretimi için $100 \mathrm{~cm} \times 100 \mathrm{~cm}$ boyutlarında kesilen jüt kumaşlar, $\mathrm{NaOH}$ yüzey modifikasyonuna tabi tutulmuştur. Modifikasyon işleminden önce kumaşlar yabancı materyallerden temizlenmek amacıyla su ile yıkanarak gölge bir alanda 24 saat boyunca kurumaya bırakılmıştır. Daha sonra jüt kumaşlar modifikasyon işlemi için \%10'luk $\mathrm{NaOH}$ çözeltisi içerisinde 4 saat boyunca bekletilmiştir. $\mathrm{Bu}$ işlemin akabinde jüt kumaşlar derişimden arındırılmak için 12 saat boyunca güneş görmeyecek şekilde açık havada kurumaya bırakılmıştır. Modifikasyon işlemi ardından kompozit malzeme üretimine geçilmiştir. 8 tabakalı kompozit malzemeler klasik el yatırma yöntemiyle simetrik $\left(0_{2 c} / 90_{2 \mathrm{j}}\right)_{\mathrm{S}}$ ve antisimetrik $\left(0_{2 \mathrm{c}} / 90_{2 \mathrm{j}}\right)_{\text {as }}$ dizilim açlarına sahip olacak şekilde üretilmiştir. Kompozit malzemelerin üretiminde örgü jüt ve E-cam kumaş olmak üzere iki farklı fiber, matris malzemesi olarak da Araldite LY 1564 epoksi reçinesi ile \%21 oranında sertleştirici Aradur3487 kullanılmıştır. Tablo 1'de doğal lif takviyeli kompozit üretiminde kullanılan fiberlerin mekanik özellikleri yer almaktadır.

Tablo 1. Kompozit üretiminde kullanılan fiberlerin mekanik özellikleri[18].

\begin{tabular}{|c|c|c|}
\hline Mekanik Özellikler & Jüt & E-cam \\
\hline Ağırlık (gr/m²) & 320 & 300 \\
\hline Çekme mukavemeti (MPa) & $393-773$ & 2306 \\
\hline Elastisite modülü (GPa) & 26,5 & 81,5 \\
\hline Kopma uzaması (\%) & $1,5-1,8$ & 2,97 \\
\hline Yoğunluk (gr/cm ${ }^{3}$ ) & 1,3 & 2,5 \\
\hline
\end{tabular}

El yatırma yönteminde ilk olarak kullanılacak kalıp silinerek, kumaşların kalıba yapışmasını engellemek için kalıba ayırıcılar sürülür. Sonra kumaşlara renk vermesi için kalıba renklendirilmiş bir reçine olan jelkot yani yüzey kaplama reçinesi sürülür. Üretimden önce kumaşlarda bulunabilecek nemin giderilmesi amaciyla kumaşlar etüvde 2 saat boyunca $60^{\circ} \mathrm{C}$ 'de bekletilerek kurumaları sağlanır. Cam ve jüt kumaşlar istenilen boyutlarda kesilerek istenilen kombinasyonlara göre yerleştirilir. Kumaşların üzerine Araldite LY 1564 epoksi reçinesi ile \%21 oranında Aradur 3487 sertleştirici karıșımı sürülür. 8 tabakalı plakalar elde edilinceye kadar kumaşlar üst üste yerleştirilir. Reçine emdirilmiş kumaşlar $120^{\circ} \mathrm{C}$ sıcaklıkta, $8 \mathrm{MPa}$ basınçta ısı ve zaman kontrollü hidrolik preste 2 saat boyunca kürleme işlemine tabi tutulur. Kürleme işlemi tamamlanan plakalar oda sıcaklı̆̆ına ulaşıncaya kadar tezgâh üzerinde soğumaya bırakılır. Daha sonra üretimi tamamlanan plakalar tezgâhtan alınarak kesme işlemi yapılır. Şekil 1'de kompozit malzemelerin üretim aşamaları görülmektedir.

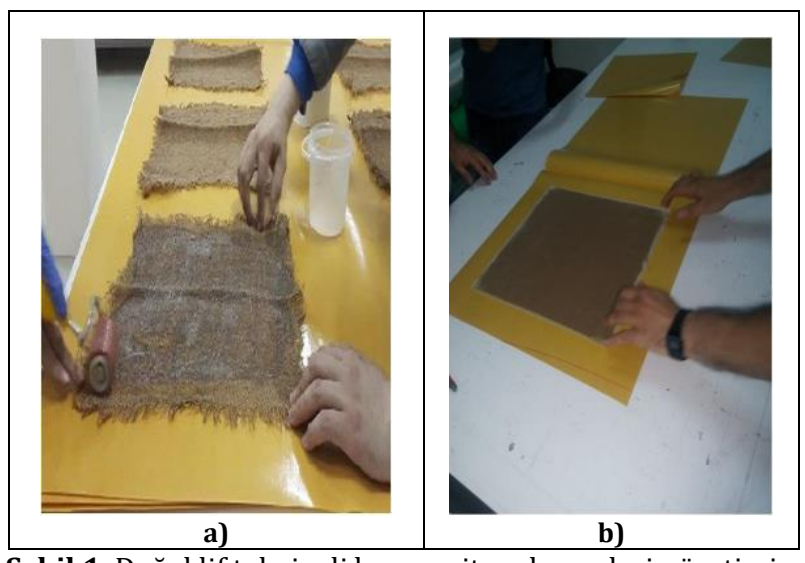

Şekil 1. Doğal lif takviyeli kompozit malzemelerin üretimi

$400 \mathrm{mmx} 400 \mathrm{~mm}$ ebatlarında ve 8 tabakalı olarak üretilen plakaların kalınlıkları $4.40 \pm 0.10 \mathrm{~mm}$ 'dir. Üretimi yapılan doğal lif takviyeli kompozit plakalardan burkulma deneyinde kullanılmak üzere 20mmx200mm boyutlarında numuneler kesilmiştir. Kompozit numunelerin tabaka dizilim açıları Tablo 2'de verilmiștir.

Tablo 2.Kompozit numunelerin tabaka dizilim açları

\begin{tabular}{|c|c|}
\hline Grup Adı & Malzeme Dizilim Açları \\
\hline $\mathrm{G}_{1}$ & $\left(0_{2 \mathrm{c}} / 90_{2 \mathrm{j}}\right)_{\mathrm{s}}$ \\
\hline $\mathrm{G}_{2}$ & $\left(0_{2 \mathrm{c}} / 90_{2 \mathrm{j}}\right)_{\mathrm{as}}$ \\
\hline
\end{tabular}

c: cam, j: jüt, s: simetrik, as: antisimetrik gösterimi ifade etmektedir

Şekil 2'de doğal lif takviyeli $\mathrm{G}_{1}$ ve $\mathrm{G}_{2}$ konfigürasyonlarına ait kompozit burkulma deney numuneleri görülmektedir.

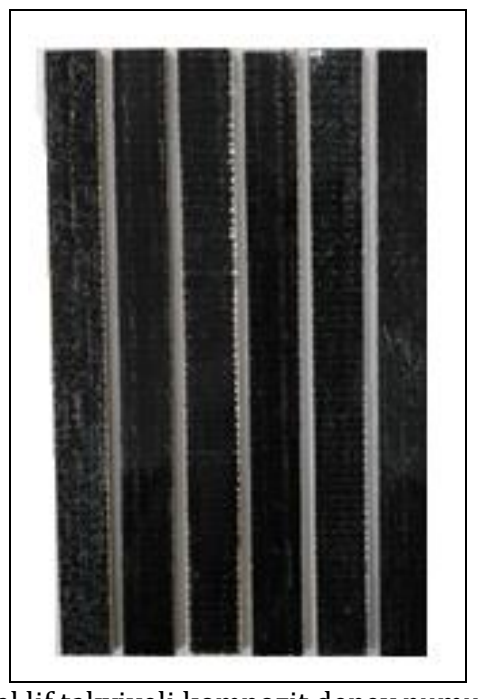

Şekil 2.Doğal lif takviyeli kompozit deney numuneleri

Doğal lif takviyeli kompozitlerin burkulma davranışı üzerine deniz suyunun etkisini araştırmak amacıyla $\mathrm{G}_{1}$ ve $\mathrm{G}_{2}$ grubu kompozit numunelerin bir kısmı laboratuvar ortamında kapalı bir kap içinde 60 gün boyunca tuzluluk oranı \%3,8 olan deniz suyunda (Akdeniz suyu) ve bir kısmı da 60 gün boyunca oda koşullarında bekletildikten sonra bulundukları 
ortamlardan alınarak hiç zaman kaybetmeden burkulma deneyine tabii tutulmuşlardır.

Burkulma deneyleri, Şekil 3'te verilen Dokuz Eylül Üniversitesi Makine Mühendisliği Bölümü Kompozit Araştırma ve Test Laboratuvarında bulunan 100 kN'luk Shimadzu AG-X çekme-basma üniversal test cihazının basma modu kullanılarak yapılmıştır. Burkulma deneyleri2 $\mathrm{mm} / \mathrm{dk}$ basma hızı ile gerçekleştirilmiştir. İki ucundan ankastre olarak mesnetlenmiş kompozit numunelerin üst kısmından düșey doğrultuda 100 kN'luk yük uygulanarak burkulma davranışları belirlenmiştir. Her bir konfigürasyon için üçer adet numune kullanılarak deneyler yapılmış ve elde edilen sonuçların ortalamaları alınmıştır.

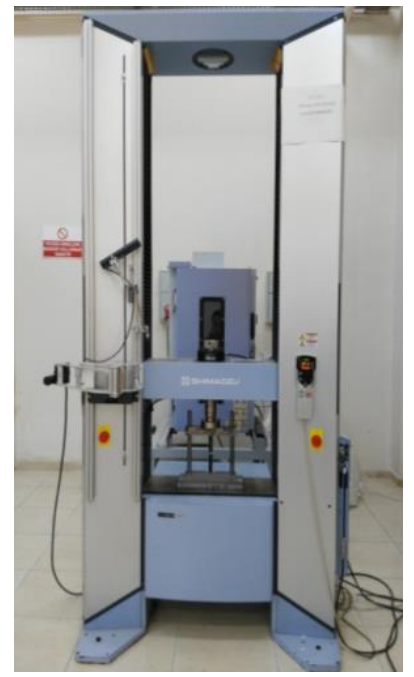

Şekil 3.Shimadzu AG-X çekme-basma üniversal test cihazı

Şekil 4'te burkulma deneyinin şematik gösterimi verilmiştir.

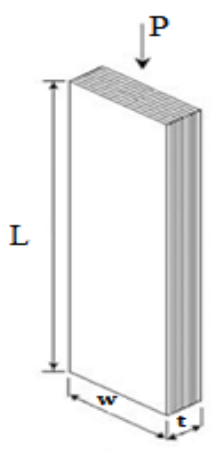

Şekil 4.Burkulma deneyi uygulanışının şematik gösterimi

Burkulma deneyinde kullanılacak doğal lif takviyeli kompozit numunelerin (L) uzunluğu 200mm, (w) genişliği 20mm'dir.

\section{Bulgular}

Deneylere başlamadan önce, kompozit numunelerin deniz suyunda bekletildiğinde ne kadar su absorbe ettiğini öğrenmek amacıyla nemlilik oranları belirlenmiştir. Numunelerin yaş ve kuru ağırlıkları hassas bir terazide tartılarak, numunelerin nem tutma oranları aşağıdaki denklem yardımıyla hesaplanabilir;

$$
\mathrm{M}(\%)=\frac{\mathrm{m}_{\mathrm{y}}-\mathrm{mk}}{\mathrm{m}_{\mathrm{k}}} * 100
$$

Burada; $m_{\mathrm{k}}$ : kuru haldeki ağırlığını, $\mathrm{m}_{\mathrm{y}}$ : yaş haldeki ağırlığını; M: yüzde olarak nem tutma oranını göstermektedir. Tablo 3'te 60 gün boyunca deniz suyunda bekletilen $G_{1}$ ve $G_{2}$ grubu numuneler için denklem (1) yardımıyla belirlenen nem tutma oranları verilmiştir. Tablodan, simetrik $\left(0_{2 c} / 90_{2 j}\right)_{s}$ dizilime sahip $\mathrm{G}_{1}$ grubu numunelerinin nem tutma oranının, antisimetrik $\left(0_{2 c} / 90_{2 j}\right)_{\text {as }}$ dizilime sahip $\mathrm{G}_{2}$ grubu numunelerine nazaran daha fazla olduğu görülmektedir.

Tablo 3.Deniz suyunda bekletilen kompozitlerin nem tutma oranları

\begin{tabular}{|c|c|}
\hline Grup adı & Nem Tutma Oranları (\%) \\
\hline $\mathrm{G}_{1}$ & 12,88 \\
\hline $\mathrm{G}_{2}$ & 5,83 \\
\hline
\end{tabular}

Deniz suyunda ve oda koşullarında bekletilen doğal kompozitlerin nem tutma oranları belirlendikten sonra her bir grup için elastisite modülü belirlenmiştir. ASTM D3039 standardına göre yapılan çekme testinde kullanılan doğal lif takviyeli kompozit numunelerin uzunluğu $200 \mathrm{~mm}$, genişliği $20 \mathrm{~mm}$ 'dir.

Deniz suyunun doğal kompozitlerin elastisite modülüne nasıl bir etkisi olduğunu belirlemek için deniz suyunda bekletilen numunelerin elastisite modülleri ile oda koşullarında bulunan numunelerin elastisite modülleri kıyaslanmıștır. Şekil 5'te deniz suyu ve oda koșullarında bekletilen $G_{1}$ ve $G_{2}$ grubu numunelerin elastisite modülleri grafik halinde verilmiştir.

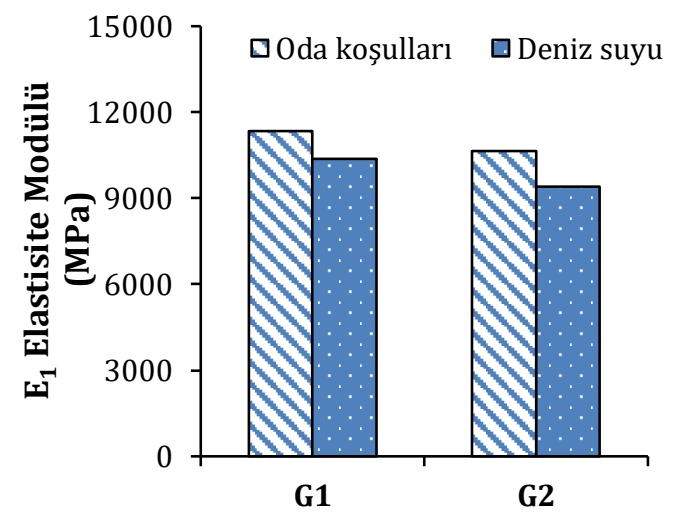

Şekil 5. $\mathrm{G}_{1}$ ve $\mathrm{G}_{2}$ grubu kompozitlerinE ${ }_{1}$ elastisite modülleri

Şekil 5'ten görüleceği üzere, deniz suyunda bekletilen kompozit numunelerin elastisite modüllerinde azalmalar meydana gelmiştir. Deniz suyunda bekletilen $\mathrm{G}_{1}$ grubu numunelerin elastisite modülü, oda koşullarına göre \%8,52 azalırken, $\mathrm{G}_{2}$ grubu numunelerin elastisite modülü $\% 11,55$ oranında 
azalmıştır. Deniz suyunun etkisi ile hem simetrik hem de antisimetrik kompozit numunelerin elastisite modülü değerinde düşüş meydana gelmiştir. Buradan hareketle doğal lif takviyeli kompozit malzemelerin simetrik ve antisimetrik dizilimine bakılmaksızın deniz suyunun kompozit malzemelerin mekanik özellikleri üzerinde olumsuz etki olușturduğu sonucuna varılmıştır. $\mathrm{Bu}$ sonuçlar literatür ile de örtüşmektedir. Gu tarafından yapılan çalışmada da deniz suyu içerisinde bekletilen kompozit numunelerin mekanik özelliklerinde azalmalar olduğunu belirtilmiştir [19]. Örçen ve Gür tarafindan yapılan çalışmada, cam fiber takviyeli dokuma epoksi kompozit malzemelere çevre şartlarının etkisi araştırılmıştır. $\mathrm{Bu}$ çalışmada, kompozit malzemeler deniz suyu içerisinde 3 ve 6 ay süre ile bekletilmiştir. En iyi mekanik özellik değerlerinin kuru haldeki numuneler için elde edildiği ve malzemelerin deniz suyu içerisinde kalma süreleri arttıkça mekanik özelliklerinde genel olarak azalmaların olduğu rapor edilmiștir [20]. Literatürdeki bașka bir çalıșmada da, fiber takviyeli kompozit malzemelerin farklı ortamlarda kullanımları için nemin, suyun ve deniz suyunun önemli bir etken olduğu ve bu faktörlerin malzemenin mekanik özelliklerini olumsuz yönde etkilediği belirtilmiștir [21].

Şekil 5'ten oda koşullarında bekletilen simetrik $\mathrm{G}_{1}$ grubu numunelerin elastisite modülünün, antisimetrik $\mathrm{G}_{2}$ grubu numunelerin elastisite modülüne göre $\% 6,35$ daha fazla olduğu belirlenmiştir. Deniz suyunda bekletilen simetrik $G_{1}$ grubu numunelerin elastisite modülü ise antisimetrik $\mathrm{G}_{2}$ grubu numunelere göre $\% 9,45$ daha fazladır. Dolayısıyla antisimetrik dizilime sahip kompozitlerin simetrik dizilime sahip kompozitlere nazaran daha düşük dayanıma sahip oldukları sonucuna varılmıştır.

\subsection{Deneysel bulgular}

Şekil 6'da 60 gün boyunca oda koşullarında bekletilen $\left(0_{2 c} / 90_{2 j}\right)_{s}$ ve $\left(0_{2 c} / 90_{2 j}\right)_{\text {as }}$ dizilimine sahip kompozit numunelerin burkulma yükü-deplasman grafiği verilmiştir.

Şekil 7'de ise 60 gün boyunca deniz suyunda bekletilen $\left(0_{2 c} / 90_{2 j}\right)_{s}$ ve $\left(0_{2 c} / 90_{2 j}\right)_{\text {as }}$ dizilimine sahip kompozit numunelerin yük-deplasman grafiği görülmektedir.

Şekil 6 ve Şekil 7'den görüleceği üzere deniz suyunda bekletilen malzemelerin burkulma dayanımı oda koşullarında bekletilen numunelerin burkulma dayanımlarına nazaran daha düşüktür. Dolayısıyla deniz suyunun malzemeler üzerinde olumsuz etki oluşturduğu sonucuna varılmıştır. Bunun nedeni olarak fiber-matris arasına yerleşen deniz suyunun korozif etkisi nedeniyle matris yapıda mikro bozunmalara ve fiber-matris arayüzeyinde zayıflamalara neden olduğu ve bunun sonucu olarak da kompozitin dayanımında düşüş meydana geldiği kanaatine varılmıştır.

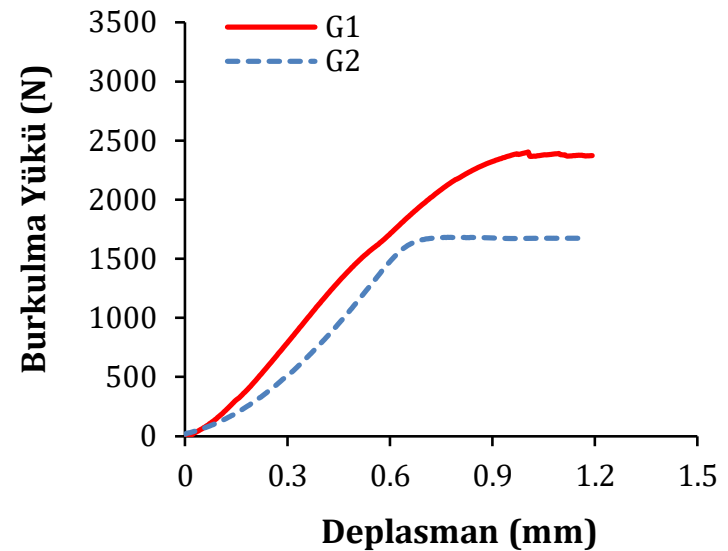

Şekil 6. 60 gün oda koşullarında bekletilen kompozitlerin yük-deplasman grafiği

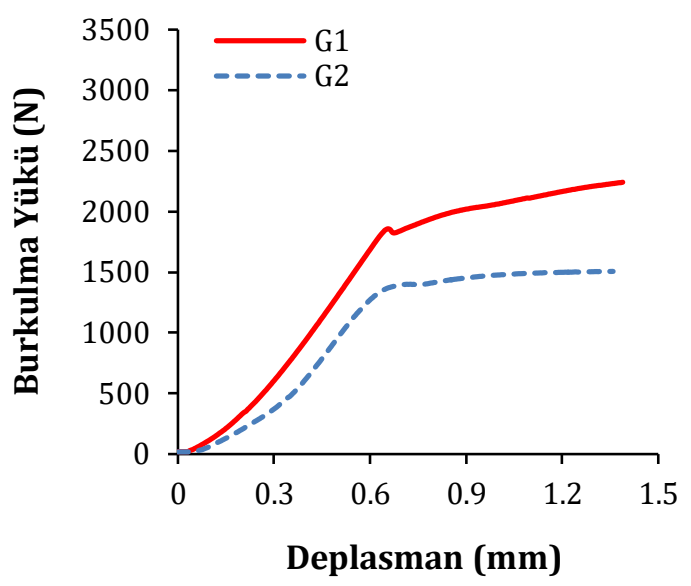

Şekil 7. 60 gün deniz suyunda bekletilen kompozitlerin yük- deplasman grafiği

Şekil 8'de kritik burkulma yük noktasının belirlenme yöntemi gösterilmiştir. $\mathrm{Bu}$ grafikteki $\mathrm{P}_{\mathrm{kr}}$, kritik burkulma yükünü tanımlamaktadır. Şekle göre eğri üzerine çizilen teğetin kesişme noktası bize kritik burkulma yükü değerini vermektedir. Kritik burkulma yükü malzemenin deformasyona uğramadan taşıyabileceği yükü belirtmektedir.

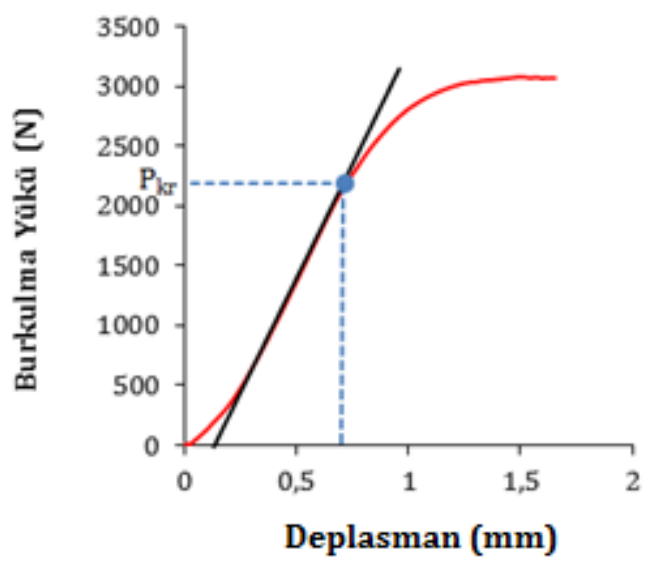

Şekil 8. Kritik burkulma yükünün belirlenmesi

Şekil 9'da $\left(0_{2 c} / 90_{2 j}\right)_{s}$ istifleme dizilimine sahip $G_{1}$ grubu kompozit numunelerin farklı ortamlardaki burkulma yükü-deplasman grafiği verilmiştir. 


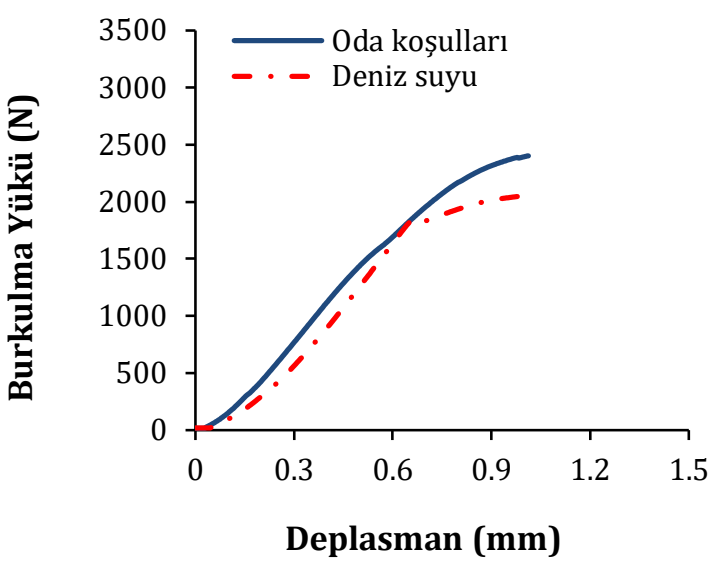

Şekil 9.G1 grubu numunelerin burkulma yükü-deplasman grafiği

Şekil $10^{\prime} \mathrm{da}\left(0_{2 \mathrm{c}} / 90_{2 \mathrm{j}}\right)_{\text {as }}$ istifleme dizilimine sahip $\mathrm{G}_{2}$ grubu kompozit numunelerin farklı ortamlardaki burkulma yükü-deplasman grafiği verilmiştir.

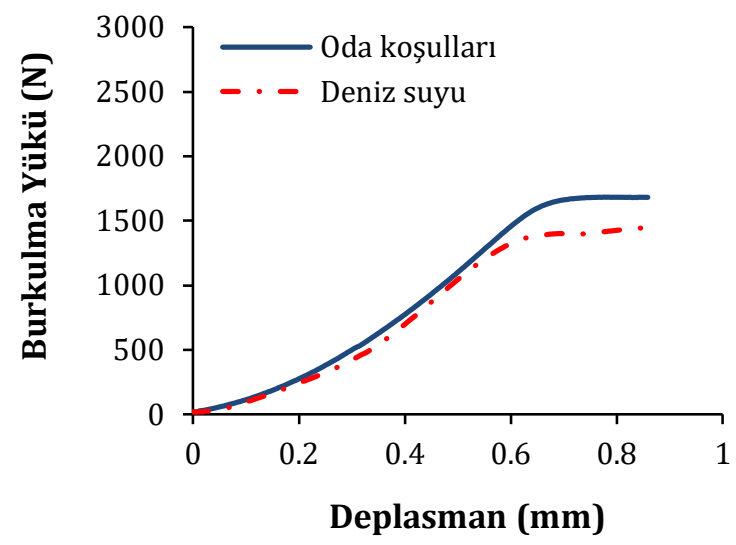

Şekil 10. G2 grubu numunelerin burkulma yükü-deplasman grafiği

Şekil 9 ve Şekil 10'dan deniz suyunda bekletilen $\mathrm{G}_{1}$ ve $G_{2}$ numunelerinin burkulma dayanımlarının oda koşullarında bekletilen $G_{1}$ ve $G_{2}$ numunelerinin burkulma dayanımlarına nazaran daha düşük olduğu görülmektedir.

Şekil 11'de oda koşulları ve deniz suyunda bekletilen $\mathrm{G}_{1}$ ve $\mathrm{G}_{2}$ grubu numunelerinin kritik burkulma yükleri karşılaştırılmıştır.

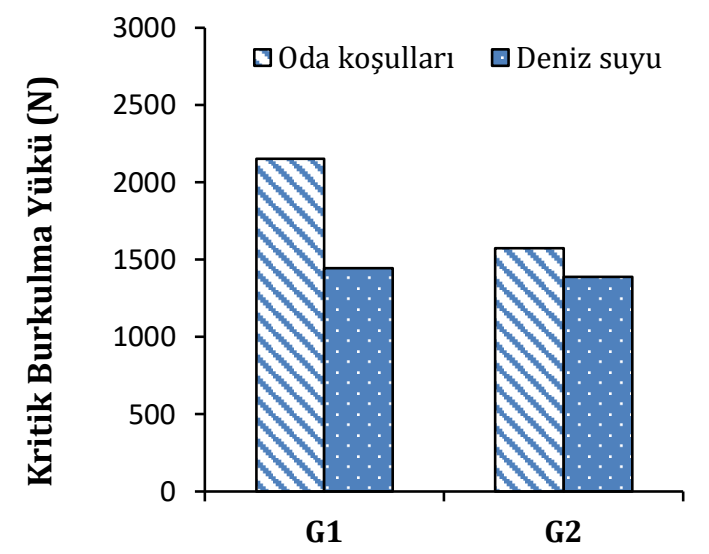

Şekil 11. Oda koşulları ve deniz suyunda bekletilen kompozitlerin kritik burkulma yükleri

Şekil 11'den görüleceği üzere, deniz suyunda bekletilen numunelerin kritik burkulma yükleri oda koşullarında bekletilen numunelerin kritik burkulma yüklerine göre daha düşüktür. $\mathrm{G}_{1}$ grubu numunelerin kritik burkulma yükü değeri oda koşullarına göre \% 33 oranında azalırken, $\mathrm{G}_{2}$ grubu numunelerin kritik burkulma yükü değeri \%11,65 oranında azalmıştır. Literatürdeki çalışmalar da bu sonuçlar ile örtüşmektedir. Karakuzu vd., cam lifi-epoksi esaslı kompozit plakaların darbe davranışı üzerine deniz suyunun etkisini araştırmışlardır. Çalışma sonucunda, deniz suyundaki tuzun, darbe enerjisinin ve darbe ucu kütlesinin kompozit plakaların darbe davranışına önemli etkisinin olduğunu belirtilmiştir [15]. Başka bir çalışmada, cam lifi-epoksi tabakalı kompozit numunelerin darbe davranışı üzerine deniz suyunun etkisi araştırılmıştır. Çalışma sonucunda, numunelerin deniz suyunda bekleme süresi arttıkça absorbe ettiği enerji miktarı azalmış ve dayanımında da azalmaların olduğu görülmüştür [22]. Aktaş ve Uzun, örgü cam fiber kompozitlerin yatak dayanımı üzerine deniz suyunun etkisini incelemişler ve deniz suyunda bekletilen numunelerin yatak dayanımlarının önemli ölçüde azaldığını rapor etmişlerdir [23]. Kompozit malzemenin deniz suyunda bekletilmesi sonucu fiber-matris arasına yerleșen tuzlu suyun korozif etkisi nedeniyle matriste mikro bozunmalar ve fiber-matris arayüzeyinde zayıflamalar oluștuğundan kompozitin burkulma dayanımında düşüş meydana geldiği kanaatine varılmıștır.

Şekil 12'de iki farklı ortamda bekletilen simetrik dizilimli $G_{1}$ ve antisimetrik dizilimli $G_{2}$ grubu numunelerinin kritik burkulma yükleri karşılaștırılmıştır [24]. Şekilden, her iki ortam için de simetrik dizilimli numunelerin kritik burkulma yükünün daha yüksek olduğu görülmektedir. Bu sonuç literatür ile de uyum içindedir. Yeter vd., simetrik ve antisimetrik dizilime sahip hibrit kompozit plakaların burkulma davranışını nümerik olarak incelemişler ve simetrik dizilime sahip kompozit numunelerin antisimetrik dizilime sahip kompozit numunelere nazaran daha iyi burkulma davranışına sahip olduklarını belirtmişlerdir [25]. Erkliğ ve Yeter tarafından yapılan çalışmada ise, simetrik ve antisimetrik dizilimli kompozit plaklarda uzunluğun ve kalınlığın burkulma davranışı üzerine etkisi araştırılmıştır. Çalışma sonucu olarak, farklı istifleme diziliminin kompozit plakaların kritik burkulma yüküne doğrudan etkisi olduğu belirtilmiştir [26]. 


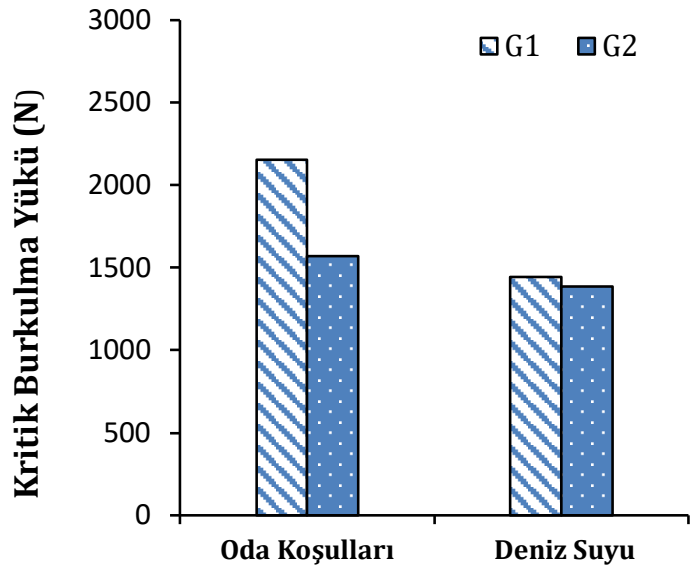

Şekil 12. $G_{1}$ ve $G_{2}$ grubu numunelerin kritik burkulma yükleri

Şekil 12'den, oda koşullarında bekletilen antisimetrik dizilimli $\mathrm{G}_{2}$ grubu numunelerin kritik burkulma yükünün, simetrik dizilimli $\mathrm{G}_{1}$ grubu numunelerin kritik burkulma yüküne göre $\% 27$ azaldığı görülmektedir. Şekilden, deniz suyunda bekletilen simetrik ve antisimetrik numunelerin kritik burkulma yükleri arasında çok fazla bir değişim gözükmemektedir. Deniz suyunda bekletilen antisimetrik dizilimli $\mathrm{G}_{2}$ grubu numunelerin kritik burkulma yükünün, simetrik dizilimli $\mathrm{G}_{1}$ grubu numunelere göre \%3.75 oranında azaldığı görülmüştür. Literatürde yapılan bir çalışmada da benzer olarak; Rashdi vd., kompozit malzemeleri farklı ortamlara maruz bırakarak, oda koşulları ile nemli ortam koşullarını karşılaştırmışlardır. Çalışmanın sonucu olarak, nemli ortamda bekletilen malzemelerin çekme mukavemetinde düşüşler olduğu rapor edilmiştir [27].

Şekil 13'te iki farklı ortam koşulunda 60 gün boyunca bekletilerek burkulma deneyi uygulanan simetrik dizilimli $\left(\mathrm{G}_{1}\right)$ ve antisimetrik dizilimli $\left(\mathrm{G}_{2}\right)$ kompozit numunelerinde meydana gelen deplasman değerlerinin değişimi verilmiştir.

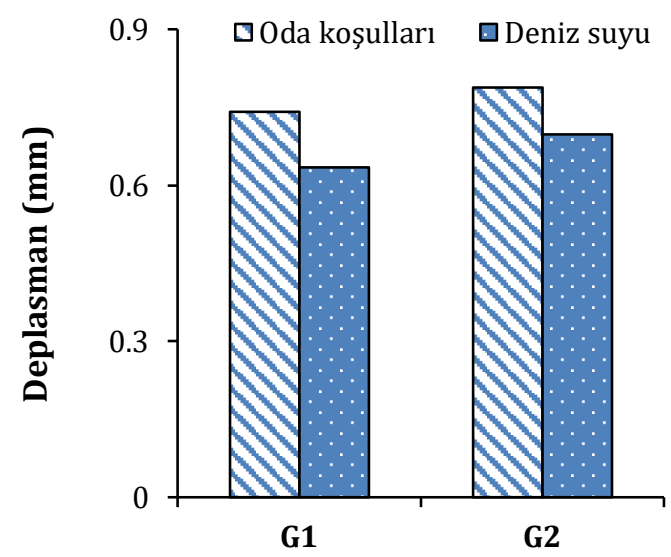

Şekil 13. Farklı ortamlarda bekletilmiş kompozitlerde meydana gelen deplasman değerleri

Şekil 13'ten görüldüğü üzere deplasman değerleri ortamlara göre değişmektedir. Oda koşullarında bekletilen numunelerin deplasman değerleri, deniz suyunda bekletilen numunelerin deplasman değerlerine göre daha yüksektir. Simetrik $\mathrm{G}_{1}$ grubu numunelerin oda koşullarındaki deplasman değeri, deniz suyuna göre $\% 14,55$ daha yüksektir. Antisimetrik $\mathrm{G}_{2}$ grubunun oda koşullarındaki deplasman değerinin, deniz suyuna göre \%11,42daha yüksek olduğu saptanmıştır. Bunun yanı sıra her iki ortam koşulunda da antisimetrik dizilimli $G_{2}$ grubu kompozitlerin deplasman değerlerinin, simetrik $\mathrm{G}_{1}$ grubu kompozitlerin deplasman değerlerine nazaran daha yüksek olduğu görülmektedir.

Doğal lif takviyeli kompozitlerin burkulma deneyi sonrası numunede oluşan deformasyon hali Şekil 14'te verilmiştir. İki ucu ankastre olarak mesnetlenmiş numune, yanal burkulmaya ve dönmeye karşı engellenmiștir. $\mathrm{Bu}$ mesnetlenme çeşidine göre numune sadece düşey yönde hareket edebilmekte ve düşey burkulmaya maruz kalmaktadır.

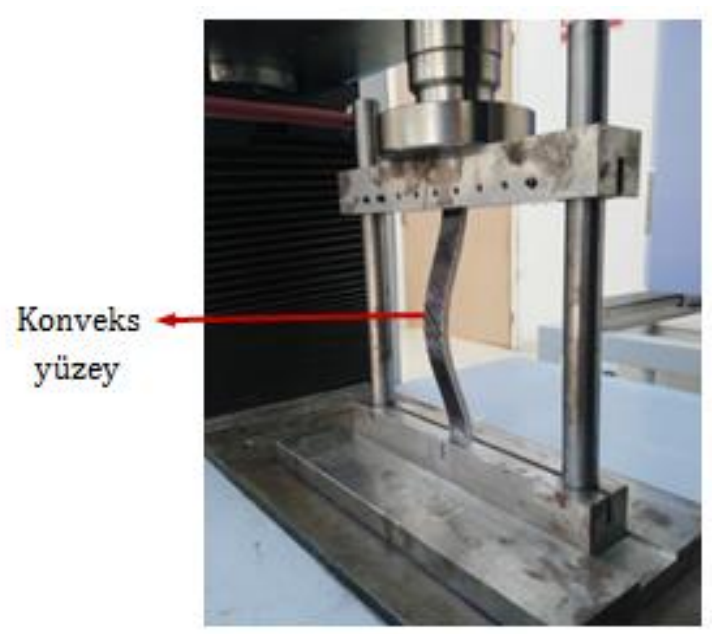

Şekil 14. Burkulmaya maruz kompozit numuneler

Numunenin burkulma yüküne maruz kalması sonucu Şekil 14'te görüldüğü üzere düşey doğrultuda eğilme oluşur. Eğilmenin oluştuğu numunenin konveks yüzeyinde, eğilmeden kaynaklanan çekme gerilmeleri ve çekme uzamaları en fazla olacağından bu yüzeyin en dış tabakasındaki lifler uzamaya maruz kalarak renk değişimine uğramışlardır (Şekil 15). Şekilden simetrik dizilime sahip $G_{1}$ grubu numunelerin burkulma deneyi sonrasında oluşan deformasyon bölgelerinde, kompozitin en diş tabakasındaki liflerin renk değişikliğine uğradığı (beyazladığı) görülmektedir. $\mathrm{G}_{2}$ grubu kompozit numunelerin burkulma deneyi sonrası oluşan deformasyonları için ön görünüşüne bakarak yorum yapılamadığından numunelerin yan görünüşleri verilmiștir.

Șekil 16'da burkulma sonrası olușan deformasyonların daha iyi görülebilmesi için simetrik $\mathrm{G}_{1}$ grubu ve antisimetrik $\mathrm{G}_{2}$ grubu numunelerin yan görünüşleri verilmiştir. 


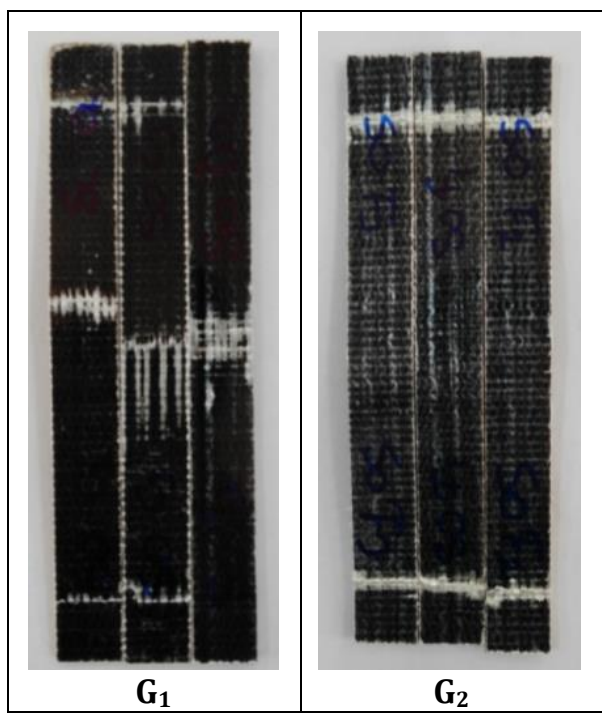

Şekil 15.Burkulma deneyi sonrası $\mathrm{G}_{1}$ ve $\mathrm{G}_{2}$ grubu kompozit numuneler (deniz suyu - 60 gün)

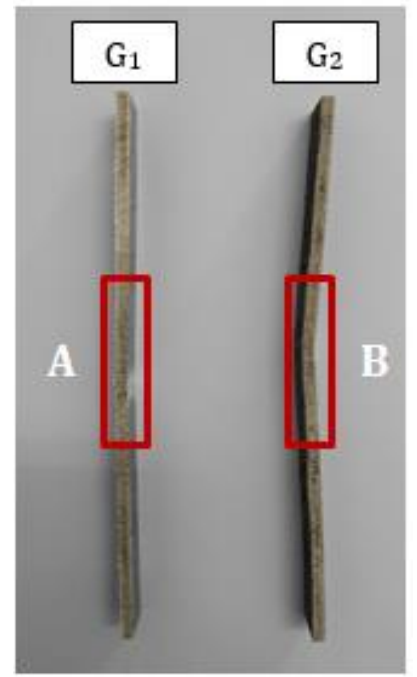

Şekil 16. Burkulma sonrası $G_{1}$ ve $G_{2}$ numunelerinde meydana gelen deformasyonlar (deniz suyu - 60 gün)

Şekil 16'dan antisimetrik dizilimli $\mathrm{G}_{2}$ grubu numunesinin, simetrik dizilimli $\mathrm{G}_{1}$ grubu numunesine göre daha fazla deformasyona uğradığı, dolayısıyla bu numunede daha fazla eğilmenin meydana geldiği görülmektedir. $\mathrm{G}_{1}$ grubu numunesinin kritik burkulma yükü $\mathrm{G}_{2}$ grubu numunesinin kritik burkulma yükünden \%27 daha büyüktür. Dolayısıyla $\mathrm{G}_{1}$ numunesi daha fazla burkulma yükü taşıma kapasitesine sahiptir. $\mathrm{Bu}$ nedenle $\mathrm{G}_{1}$ grubu, $\mathrm{G}_{2}$ grubuna nazaran daha az deformasyona uğramıștır. Literatürde; karbon, S-cam ve aramid fiberlerinin farklı kombinasyonlarını içeren tabakalı hibrit kompozit plakaların burkulma davranışları araştırılmıştır. Çalışmanın sonucu olarak hibrit kompozit malzemelerin farklı fiber ve oryantasyon açılarının burkulma davranışlarını doğrudan etkilediği belirtilmiştir [28].

Şekil 17'de $\mathrm{G}_{1}$ grubu numunesinin deformasyon bölgesinden $A$ kesiti, $G_{2}$ grubu numunesinin deformasyon bölgesinden $B$ kesiti alınarak bu bölgelerde oluşan hasar modları ayrı ayrı gösterilmiştir.

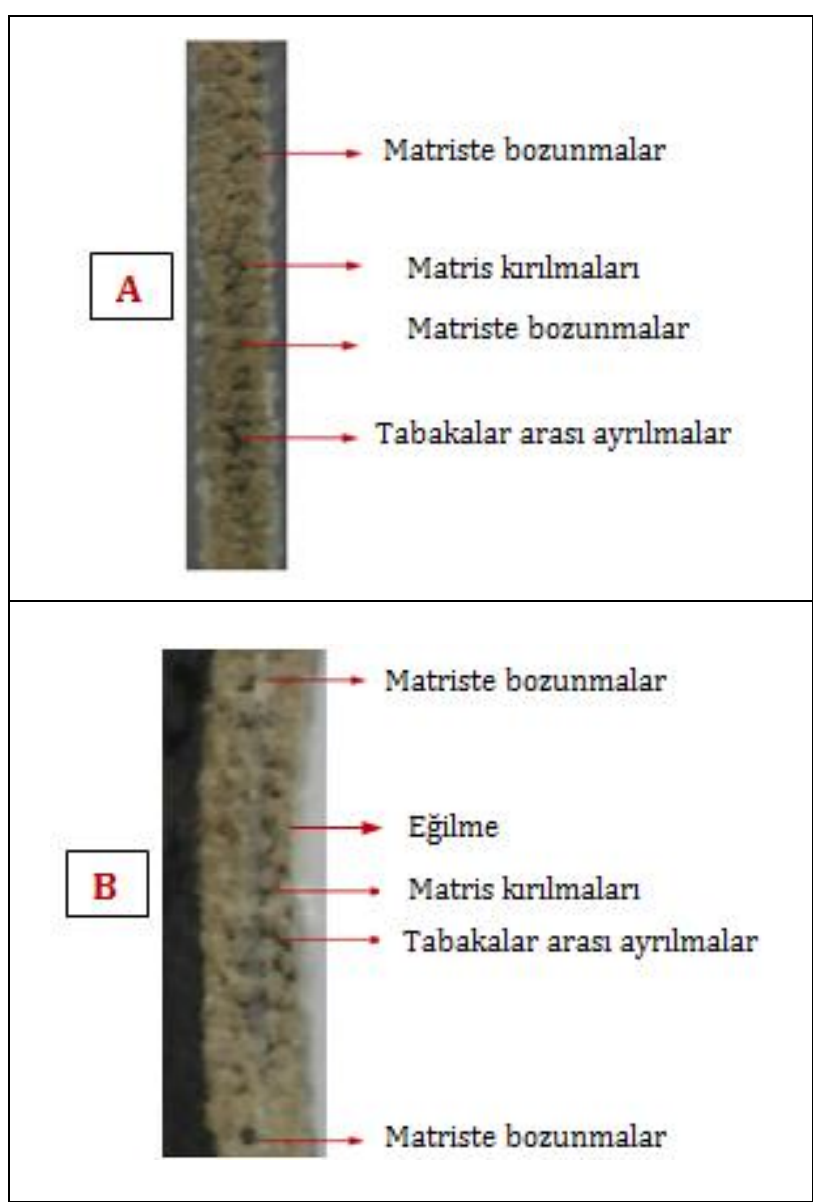

Şekil 17. Deformasyon bölgesinden alınan A ve B kesitleri

Şekil 17'den görüldüğü üzere, $A$ ve $B$ kesit görüntülerinde $G_{1}$ ve $G_{2}$ grubu numunelerinin deformasyon bölgelerinde tabakalar arası ayrılmalar, matriste bozunmalar ve matris kırılmaları şeklinde hasar modları meydana gelmiștir. $\mathrm{G}_{2}$ grubu numunesinin (B kesit görüntüsü) deformasyon bölgelerinde de tabakalar arası ayrılmalar, matriste bozunmalar ve matris kırılmaları yanında kalıcı eğilme deformasyonu oluştuğu görülmektedir.

\section{Tartışma ve Sonuç}

$\mathrm{Bu}$ çalıșmada, doğal lif takviyeli kompozit malzemelerin burkulma dayanımları deneysel olarak incelenmiştir. Yapılan çalışmalar sonucunda, simetrik ve antisimetrik istifleme dizilimli doğal kompozitlerin burkulma davranışına deniz suyunun etkileri araştırılmış ve aşağıdaki sonuçlar elde edilmiştir:

- Deniz suyunda bekletilen doğal kompozitlerin elastisite modülü değerlerinde, oda koşullarında bekletilen numunelere göre azalmalar meydana gelmiştir.

- Simetrik $\mathrm{G}_{1}$ grubu numunelerin elastisite modülü değerinin, antisimetrik $G_{2}$ grubu numunelerine göre daha fazla olduğu görülmüştür. 
- Deniz suyunun ve farklı istifleme diziliminin doğal kompozit numunelerin kritik burkulma yüküne doğrudan etki ettiği görülmüştür.

- Deniz suyunda 60 gün bekletilen doğal kompozitlerin kritik burkulma yükleri, oda koşullarında bekletilen numunelerin kritik burkulma yüklerine nazaran daha düşüktür.

- Her iki ortam için de simetrik istifleme dizilime sahip $\mathrm{G}_{1}$ grubu numunelerin kritik burkulma yükü değerlerinin, antisimetrik dizilimli $\mathrm{G}_{2}$ grubuna göre daha yüksek olduğu görülmüștür.

- Her iki ortam koşulu için de en yüksek kritik burkulma yükü değerleri, oda koşullarında bekletilen simetrik $\left(0_{2 c} / 90_{2 j}\right)_{s}$ dizilime sahip $G_{1}$ grubu kompozit numunelerde görülmüştür.

- Her iki ortam koşulu için de en düşük kritik burkulma yükü değerleri, deniz suyunda bekletilen antisimetrik $\left(0_{2 c} / 90_{2 j}\right)$ as dizilime sahip $\mathrm{G}_{2}$ grubu kompozit numunelerde görülmüştür.

- Deniz suyunda bekletilen antisimetrik dizilimli $\mathrm{G}_{2}$ grubu kompozit numunesinin, simetrik dizilimli $\mathrm{G}_{1}$ grubu kompozit numunesine göre daha fazla kalıcı deformasyona uğradığı görülmüştür.

- Deniz suyunda bekletilen numunelerin burkulma sonrası oluşan deformasyon bölgelerinde tabakalar arası ayrilmalar, matriste bozunmalar ve matris kırılmaları şeklinde hasar modları meydana gelmiştir.

- Nem ve tuzlu suyun doğal lif takviyeli kompozit malzemelerin burkulma dayanımını olumsuz yönde etkilediği sonucuna varılmıştır.

- Deniz suyunda bekletilen numunelerde oda koşullarında bekletilen numunelere göre daha fazla eğilme oluşmuştur. Bunun nedeni olarak kompozit malzemenin deniz suyunda bekletilmesi neticesi su emmesi ve emilen suyun kompoziti yumuşatması sonucu kalıcı şekil değiştirmeye neden olduğu düşünülmektedir. Ayrıca deniz suyunun korozif etkisi nedeniyle fiber-matris arayüzeyinin bozunması ve fiberlerin aşınması sonucu kompozit malzemede daha fazla kalıcı hasara neden olduğu kanaatine varılmıştır.

Sonuç olarak; deniz suyunda bekletilen doğal lif takviyeli kompozitlerin burkulma dayanımı oda koşullarında bekletilen doğal lif takviyeli kompozit numunelere nazaran düşüktür. Kompozit malzemenin deniz suyunda bekletilmesi sonucu malzeme su emer ve emilen su neticesinde malzemede şişme ve kalıcı şekil değiştirmeler oluşur. Fiber-matris arasına yerleșen tuzlu suyun korozif etkisi nedeniyle matriste mikro bozunmalar ve fibermatris arayüzeyinde zayıflamalar oluştuğundan kompozitin dayanımında düşüş meydana geldiği kanaatine varılmıștır. Bu nedenle kompozit malzeme üretimi yapılırken kompoziti oluşturan matris ve fiberlerin seçimi malzemenin kullanılacağı ortam koşuluna uygun olacak şekilde yapılmalıdır. Malzemelerin hangi ortam koşullarına maruz kalacağı göz önünde bulundurularak uygun fiber istiflemesi belirlenerek ona göre üretim yapılmalıdır. Ayrıca maruz kalabileceği zorlanmalara (eğilme, burulma ve burkulma vb.) karşı dayanıklı, yük taşıma kapasiteleri fazla olan malzemelerin seçilmesi önerilir.

\section{Teşekkür}

Bu çalışma, Süleyman Demirel Üniversitesi Bilimsel Araştırma Projeleri Koordinasyon Birimi tarafından 5060-YL1-17 nolu proje kapsamında desteklenmiştir. SDÜ Bilimsel Araştırma Projeleri Koordinasyon Birimi Başkanlı̆̆ı'na katkılarından dolayı teşekkür ederiz. Ayrıca kompozit malzemelerin üretimini gerçekleștiren Fibermak firmasına ve burkulma deneylerinin yapıldığı Dokuz Eylül Üniversitesi Makine Mühendisliği Bölümü'ne de teșekkürlerimizi sunarı.

\section{Kaynakça}

[1] Ku, H, Wang, H, Pattarachaiyakoop, N., Trada, M., 2011. A Review on the Tensile Properties of Natural Fiber Reinforced Polymer Composites. Composites: Part B, 42, 856-873.

[2] Olusegun, D.S., Stephen, A., Timothy, A.A., 2012. Assessing Mechanical Properties of Natural Fiber Reinforced Composites for Engineering Applications. Journal of Minerals and Materials Characterization and Engineering, 11, 780-784.

[3] Seki, Y., Akşit, A., 2015. Farklı Kimyasal Maddeler ile Modifiye Edilen Jüt Liflerinin Mekanik ve Morfolojik Özelliklerinin İncelenmesi, XIX. Ulusal Mekanik Kongresi, 854862.

[4] Mohanty, S., Verma S. K., Nayak S. K., 2006. Dynamic Mechanical and Thermal Properties of MAPE Treated Jute / HDPE Composite. Composites Sience and Technology, 66, 538-547.

[5] Karabulut, N., Aktaş, M., 2014. Jüt Lifi Takviyeli Kompozitlerin Mekanik Özelliklerinin Yüzey Modifikasyon İşlemiyle İyileştirilmesi, Mühendis ve Makina, 55 (649), 43-49.

[6] Ramesh, M., Palanikumar, K., Hemachandra Reddy, K., 2013. Mechanical Property Evaluation of Sisal-Jute-Glass Fiber Reinforced Polymer Composites. Composites: Part B, 48, 1-9.

[7] Liu, X.Y., Dai, G.C., 2007. Surface Modification and Micromechanical Properties of Jute Fiber Mat Reinforced Polypropylene Composites. Express Polymer Letters, 1(5), 299-307.

[8] Bulut, Y., Erdoğan, U.H., 2011. Selüloz Esaslı Doğal Liflerin Kompozit Üretiminde Takviye 
Materyali Olarak Kullanımı. The Journal of Textiles and Engineers, 82, 26-35.

[9] Singh, B., Gupta, M., Verma, A., 2000. The Durability of Jute Fibre-Reinforced Phenolic Composites. Composites Sience and Technology, 60, 581-589.

[10] Akil, H.M., De Rosa, I.M., Santulli, C., Sarasini F., 2010. Flexural Behaviour of Pultruded Jute / Glass and Kenaf/Glass Hybrid Composites Monitored Using Acoustic Emission. Materials Sience and Engineering A 527, 2942-2950.

[11] Boccardi, S., Carlomagno, M.G., Meola, C., Russo, P., 2018. The Contribution of Infrared Thermography in the Characterization of Jute Based Composites. Composite Structures, 190, 119-126.

[12] Chaudhari, V., Chandekar, H., Saboo, J., Mascarenhas, A., 2018. Studies on ThermoMechanical Properties of Chemically Treated Jute-Polyester Composite. Materials Science and Engineering, 330, 1-9.

[13] Akbulut, H., Sayman, O., 2001. An Investigation on Buckling of Laminated Plates With Central Square Hole. Journal of ReinforcedPlastics and Composites, 20(13), 1112-1124.

[14] Gençoğlu, M., 2011. Tabakalı Kompozit Levhalarda Burkulma Analizi. Fırat Üniversitesi, Fen Bilimleri Enstitüsü, Yüksek Lisans Tezi, 159 s, Elazı ̆̆.

[15] Chakrabarti, A., Sheikh, H. A., 2006. Buckling of Composite Laminates Subjected to in-Plane Partial Edge Compression Using a Refined Plate Theory. Journal of Reinforced Plastics and Composites, 25, 1189-1204.

[16] Karakuzu, R., Çalık, İ.C., Deniz, M.E., 2017. Tabakalı Kompozit Plakaların Darbe Davranışı Üzerine Deniz Suyu Etkisinin Araştırılması. Batman Üniversitesi Yaşam Bilimleri Dergisi, 7 (2/2), 1-12.

[17] Zamri M.H., Akil, H.Md., Abu Bakar, A., Ishak, Z.A.M., Cheng, L.W., 2011. Effect of Water Absorption on Pultruded Jute/G

[18] Fibermak Composites, 2017. Karbon Fiber Twill Kumaşlar Erişim tarihi: 25.04.2018.http://www.fibermakcomposites. com/shop/karbon-fiber-kumas-carbon-fiber fabric/karbon-fiber-twill-kumaslar.
[19] Gu, H., 2009. Behaviours of Glass FiberUnsaturated Polyester Composites Under Seawater Environment. Materials and Design, 30, 1337-1340.

[20] Örçen, G., Gür, M., 2011. Cam Fiber Takviyeli Dokuma Epoksi Kompozit Prepreglerin Mekanik Özellikleri Üzerinde Çevre Șartlarının Etkisi. 18.Ulusal Mekanik Kongresi, Frrat Üniversitesi, 1-10, Elazı̆̆

[21] Doğan, A., 2014. Farklı Çevresel Koşullara Maruz Kompozitlerin Mekanik Davranışları, Dokuz Eylül Üniversitesi, Fen Bilimleri Enstitüsü, Yüksek Lisans Tezi, 67s, İzmir.

[22] Calık, C. İ., 2010. Deniz Suyunun Tabakalı Kompozitlerin Darbe Davranışı Üzerindeki Etkisinin Araştırılması. Dokuz Eylül Üniversitesi, Fen Bilimleri Enstitüsü, Yüksek Lisans Tezi, 50s, İzmir.

[23] Aktaş, A., Uzun, İ., 2008. Seawater Effect on Pinned-Joint Glass Fibre Composite Materials. Composite Structures, 85, 59-63.

[24] Muzoğlu, M., 2018. Farklı Ortam Koşullarında Bekletilen Doğal Lif Takviyeli Kompozitlerin Burkulma Davranışlarının Deneysel Olarak İncelenmesi. Süleyman Demirel Üniversitesi, Fen Bilimleri Enstitüsü, Yüksek Lisans Tezi, 89s, Isparta.

[25] Yeter, E., Erkliğ, A., Bulut, M., 2014. Hybridization Effects on the BucklingBehavior of Laminated Composite Plates. Composite Structures,118, 19-27.

[26] Erkliğ, A., Yeter, E., 2012. The Effects of Cutouts on BucklingBehavior of Composite Plates. Article in Science and Engineering of Composite Materials, 323-330, Berlin.

[27] Rashdi, A. A. A., Sapuan, S. M, Ahmad, M. M. H. M, Khalina, A. 2010. Combined Effects of Water Absorption due to Water Immersion, Soil Buried and Natural Weather on Mechanical Properties of Kenaf Fibre Unsaturated Polyester Composites (KFUPC). International Journal of Mechanical and Materials Engineering, 5 (1), 1117.

[28] Yeter, E., 2013. Buckling Effect Investigation of Hybrid Laminated Composite Plate. Gaziantep Üniversitesi, Fen Bilimleri Enstitüsü, Makine Mühendisliği Anabilim Dalı, Doktora Tezi, 161s, Gaziantep. 